\title{
Review of Joshua Gans (forthcoming 2020). Economics in the Age of Covid-19
}

\section{Cambridge, MA: MIT Press. DOI 10.21428/a11c83b7.c48fa91b (E-Book)}

\section{Benjamin Green ${ }^{1}$}

Published online: 6 June 2020

(C) Springer Nature Switzerland AG 2020

Keywords Covid-19 Collective intelligence $\cdot$ Pandemic economics $\cdot$ Postdigital $\cdot$ Peer-topeer publishing $\cdot$ Public health

\section{Confronting a Grim Discourse}

Written in an unpretentious conversational style, Economics in the Age of Covid-19 (Gans 2020a) provides an accessible overview of the past, present, and future economic choices confronting nations grappling against the viral pandemic of Covid-19. In highlighting the need to 'refrain from being judgmental,' Joshua Gans seeks to cement the significance of this work through a depoliticized evaluation that abstains from politics, neither 'applauding' nor 'disdaining' specific Covid-19 policies (Gans 2020a: Preface: 2). Within a sociopolitical climate marked by 'post-truth' misinformation (Jandrić 2017: 144), a purposeful adherence to Thomas Carlyle's view of economics as the 'dismal science' (Gans 2020a: Chap. 8: 4) highlights the author's resolute objectivist intent.

This intent, however implausible, is well-suited to confronting the false dichotomy currently manifesting within a global US-led 'grim economics' discoursal framework (The Economist 2020; Saphir and Mason 2020). As governments around the globe struggle to answer the questions of when and how to 'reopen' their societies, US decision-makers continue to position the health of their most vulnerable citizens as impediments to US economic survival, framing Covid-19-related deaths as necessary sacrifices which avert the destruction of the 'American way of life' (Kelley 2020).

While this book may prove valuable in its contribution to the developing field of peer-to-peer collective intelligence, its immediate and critical contribution is highlighted most clearly within its attempts to deliver a necessarily depoliticized and objective

Benjamin Green

Benbo83@gmail.com

1 Beijing Normal University, Beijing, China 
economic perspective aimed at dismantling the false dichotomy of health vs. wealth (Frias 2020). Gans' central thesis holds that it makes the most long-term economic sense for governments to sacrifice the economy in order to save lives and 'hold the line on public health' (Gans 2020a: Chap. 1: 6). The central theme of this book can be summarized aptly by the title of the first chapter-Health Before Wealth.

\section{A Methodology In Absentia}

Within a month's time, Economics in the Age of Covid-19 (Gans 2020a) was written, peer-reviewed, and published with the support of the Knowledge Futures Group, itself a partnership between MIT Press and MIT Media Labs. ${ }^{1}$ Specifically, Gans' manuscript was subjected to a dual-track process of open/peer review within the Knowledge Futures Group's ‘open-access/open-source community publishing platform' known as PubPub. $^{2}$ While MIT Press ensured a '1-week' turnaround within a more traditional peer review process, the manuscript was simultaneously posted on PubPub, allowing for another ostensibly 'open' community review process to unfold (Gans 2020a). Subsequent a revision which accounted for both open and peer feedback, the author revised and submitted the final draft to MIT Press for online publication - the entire process having taken place over the course of about two weeks - from April 7th (first draft) to April 22nd (publication) (Gans 2020a). Lastly, at the time of writing, this book has not yet completed the process of publication, having been left open to public review (formally closed on May 15, 2020, yet still open to comments) on the MIT Press PubPub online peer-review platform. ${ }^{3}$

While this approach may represent a novel contribution to the ongoing project of digital peer-to-peer collaboration within the field of collective intelligence (at least in terms of sheer speed), it posits some challenges for this review and (academic) engagement with the book in general. Specifically, ascertaining the overall merits of this book-ambiguous in its objectivity, incomplete in form, and splintered in structure-requires an uncomfortable level of subjectivity which will quite often test the limits of readers' capacity and taste for deductive reasoning. Highlighting this point, each chapter is presented by the publisher as a standalone piece with its own digital object identifier (DOI), and as per the recommendation of MIT Press, chapters are referenced individually. Moreover, as a description of this dual-track peer-to peer collaborative process (as might have been outlined within a welcome chapter on methodology) remains decidedly absent, and methodological insights are necessarily ascertained from within another such open-source Knowledge Futures Group project.

Malone and Bernstein's Handbook of Collective Intelligence (2015) (also published by MIT Press and its Knowledge Futures Group) highlights 'organization, motivation and quality' as ongoing concerns within the field (Benkler et al. 2015: 176). While Gans' work may yet constitute a 'novel, creative and unprecedented' (Benkler et al. 2015: 195) contribution to the field of peer-to-peer knowledge production, the chapters also reflect well the inherent strengths, weaknesses, and methodological constraints of

\footnotetext{
${ }^{1}$ See https://www.knowledgefutures.org/. Accessed 22 May 2020.

${ }^{2}$ See https://www.pubpub.org/about. Accessed 24 May 2020.

${ }^{3}$ See https://www.pubpub.org/. Accessed 22 May 2020.
} 
such a novel undertaking. Malone and Bernstein further highlight that, within a framework of solving complex societal problems, the project of collective intelligence may contribute to the social sciences by analyzing the intelligence of market mechanisms and the decision-making processes of governments as a whole (2015: 5). However, Gans quite simply states that this 'hastily written book' (his words) aims to 'evaluate the reasonableness of decisions being made' via an 'urgent' economic accounting of Covid-19 (Gans 2020a: Preface: 2).

\section{An Economist Speaks: Should We Listen?}

This book may be read as two parts of a somewhat fragmented whole. Part 1 (Chapters 1-4) represents a form of narrative-as-analysis, accomplishing the stated aims of 'explaining the economic issues (sic) of all this' (Gans 2020a: Preface: 2), an expert task to which the author (as an economist) states he is well-suited. Part 2 (Chapters 5-8) is presented as an attempt to forecast potential 'take-aways' that, moving forward, a global society at risk might 'want to reflect upon' — an interdisciplinary task rife with potential academic overreach which (the author readily admits) might find him completely in the wrong (Gans 2020a: Preface: 2). The first four chapters found me heartened by the author's uncanny ability to offer up a pragmatic economic perspective which abstains from political, moral, and, most surprisingly, dehumanizing (overly technical) rhetorical devices. In this way, the author adroitly humanizes an expert rationale for putting public health (saving lives) ahead of the economy. However, the remaining chapters offer significantly less in the way of concrete findings or analysis, crisscrossing in equal parts between expert economic opinion, historical review, storytelling, and admittedly amateurish (albeit entertaining) conjecture regarding a much too-wide swath of epidemiological/sociopolitical fields of study.

\section{A Word to the Wise}

Part 1 frames the global sociopolitical backdrop of engagement with the Covid-19 virus, utilizing a production possibilities frontier (PPF) of the diminished (health vs. wealth) pandemic-based 'options' framework to justify the central thesis of 'prioritizing health before wealth' (Gans 2020a: Chap 1: 6). Gans concludes that accomplishing this life-saving endeavor within free (self-interested) societies, where 'leaders downplay the magnitude of the crisis,' will result in a costly loss of 'time and, by extension, life' (Gans 2020a: Chap 1: 6). Chapter 2 highlights the mathematics of viral reproduction (R0) as a basis for the argument that governments in possession of critical information that highlighted the virality of Covid-19 had no plausible excuse to hesitate in their implementation of 'social distancing' measures. The author concludes by stating that indecisive governments were hampered by issues relating to 'transparency,' 'style of government,' and 'incompetent leadership,' having most likely based their irrational decisions to wait on 'political rather than scientific news' (Gans 2020a: Chap 2: 11). Throughout both chapters, in keeping with the aforementioned objectivist aims, the author never overtly lays blame on the Trump administration for downplaying the magnitude of the crisis or for failing to shut down the USA in time. However, despite the author's deft political avoidances, the implications are nevertheless quite explicit. 
Chapter 3 provides a comparison of centralized vs. decentralized state responses, outlining that while many decentralized states acted too late, most were quick to abandon market logic in favor of strictly controlled policies aimed at 'surfing the curve' (temporary expansion of health care capacity to meet pandemic demand) (Gans 2020a: Chap 3: 4-5). Highlighting his surprise, the author states that, rather than exhibiting the necessary 'war-like resource allocation mind-set,' 'in the US, despite having the power to do so, no central action was being taken' (Gans 2020a: Chap 3: 7). This is Gans' first clear critique of the US response to the Covid-19 pandemic. Chapter 4 represents a 'rounding out' of Gans' central unifying claim. He utilizes the analogy of 'pressing pause' on the economy as akin to affecting a necessary and healthy recession as a means of staving off what he refers to as a 'dark recession' (long-term pandemic-borne damage to workforce/economy) (Gans 2020a: Chap 4: 4).

Gans' findings support his unifying central thesis that sacrificing the economy in the short term (while providing income-fixed government loans) will not only save lives but also protect the economy in the long run. Here Gans presents his strongest critique of the US-led 'grim economics' based on political discourse which irrationally calls for a sacrificing of elderly lives to benefit the economy (Levin 2020). He effectively dismantles the false health vs. wealth dichotomy while providing a rationale for the short-term pursuit of health over wealth as a means for ensuring long-term postpandemic market potential.

\section{Runaway Narrative}

Chapter 2 begins with a discussion surrounding the hypothetical development of two types of Covid-19 testing economy-'Have' (testing those who have it) and 'Had' (testing those who had it). The author then highlights that the emergence of a 'Have' testing economy would be more useful than 'Had,' as the attainment of such critical information (subsequent the wide availability of less imperfect testing procedures) would allow governments to avail themselves of more cost-effective alternatives to blanket isolation measures (Gans 2020a: Chap 5: 6). The most valuable insight remains the author's explanation of how, absent the crucial information provided by these forms of testing, the only viable option for stopping the spread of Covid-19 are strict blanketisolation measures (Gans 2020a: Chap 5: 3).

Chapter 6 has the author straying further from his area of expertise, descrying the notion that governments are facing 'political pressures' to begin plotting a path out of isolation (Gans 2020a: Chap 6: 2). Stressing that, absent a vaccine or any coherent centralized strategy for preventing 'future un-contained outbreaks,' a politically motivated exodus could prove exceedingly deadly (Gans 2020a: Chap 6: 2). Given the fact that currently there exists a faction of US leadership (backed by politically charged civil protests groups) (Villa 2020) which supports a seemingly irrational and perhaps premature (Berger et al. 2020) opening up of society, this statement reads as especially prescient, yet undoubtedly politicized. Gans argues very clearly against such an inopportune reopening, stating that any reopening of the economy should coincide with the introduction of a testing society which allows for the targeted release of essential industry personnel rather than a universal lifting of quarantine measures (Gans 2020a: Chap 6: 6).

Chapter 7 centers around the question how can society, given US patent laws, promote the innovation of vaccines for the public good without traditional market- 
based incentives. After highlighting the need to innovate outside market logic, Gans inexplicably utilizes market logic to suggest that advanced market commitments (AMC) may ensure research and development innovation within multiple avenues of fixed-price (yet market-driven) development. Gans then states that pandemic societies need to change their risk-adverse mentalities - pursuing riskier 'unconventional' approaches in order to pursue a wider range of available scientific innovations with potentially higher rewards (Gans 2020a: Chap 7: 7). At this point, Gans strays even further from his given field of expertise, engaging both the field of collective intelligence and global governance. He suggests that an audited intergovernmental framework for innovation, as a form of open and expert collaboration (i.e., 'A new Manhat$\tan$ Project'), is required to foment innovation on a global scale for the collective public good (Gans 2020a: Chap 7: 7).

\section{Collective Intelligence or Myopic Postdigitalism}

Bearing the brunt of this critical appraisal, the final chapter provides a platform for a collective intelligence-centered discussion of the book's inherent methodological shortcomings. The chapter begins with a cringe-inducing praise of the Bretton Woods system, with Gans highlighting the much-maligned IMF (of all institutions) as a paragon of post-war liberal international cooperation (Gans 2020a: Chap 8: 2). However, in sidestepping any mention of imbalance within an international system, which favors the west and foments a globalism based in western ideals, Gans invites a more detailed critique of methodology. Specifically, as concerns the aforementioned issue of 'organization' within the current era of postdigital collective intelligence, this glaring omission reflects the concern that collective intelligence may represent 'a digital process which might be reproducing cultural assumptions whilst silencing aspects of non-western culture' (Jandrić et al. 2018).

Highlighting an implicit form of neocolonial Euro-centrism, the author's temperate critique of the US does not, however, extend to his reproving discussion of China. Specifically, the author not only states that that the virus started in Wuhan, but also states that the global spread of Covid-19 was a result of China's 'confined response' - a 'governance problem' which might have been mitigated within a more 'open' system. However, most fatally, the author unreservedly (and on numerous occasions) labels Taiwan as a separate and distinct country apart from China (Gans 2020a: Chap 5: 11; Chap 8: 2). While perhaps true in some regards, these statements can only be read as either purposefully political or extremely uninformed. Clearly, any detailed reading of the Chinese scholarly position on these three fronts would have led to a more inclusive reframing of these (within China) very polemic statements. These critical missteps highlight the notion that inequitable power dynamics continue to perpetuate within the process of postdigital peer production. As otherwise stated within Malone and Bernstein's Handbook of Collective Intelligence: 'feedback loops of attention and cumulative advantage can perpetuate a starkly unequal distribution of influence and hierarchy' (Benkler et al. 2015: 181). Therefore, the question remains - has the unprecedented (and somewhat audacious) speed of this book's open/peer review process affected a less inclusive form of peer-to-peer collaboration? In this regard, Gans' Economics does provide a key methodological insight for the field of collective intelligence. Specifically, it leaves one with the understanding that perhaps a 2 -week 
review and revise process (for a book as aspirational as this) may not provide enough time to acquire, assess, and incorporate an adequately diverse and insightful range of perspectives and critiques.

Moving on, perhaps the only valid (expert) point within this chapter lies within Gans' argument that if the statistical value of a life is $\$ 10$ million, even a modest sized loss of life would be worth the potential economic cost of future pandemic prevention measures (Gans 2020a: Chap 8: 5). The implication being that within a current reality where (at the time of writing) 95,000 deaths (NBC News 2020) have resulted from the US' mismanaged response to Covid-19, the Trump administration can be looked at as responsible for (thus far) the loss of 950 billion USD. Finally, Gans concludes that spending a few hundred billion dollars to prevent a global pandemic is 'as close to a nobrainer as we are likely to get' (Gans 2020a: Chap 8: 5). Gans ends the chapter by opining that subsequent to the successful eradication of Covid-19, global institutions must be built upon a collective resolve to ensure that the 'preservation of life' is understood to be the 'true benefit' of pandemic prevention (Gans 2020a: Chap 8: 5). While Gans' misguided ideological framework warrants admonition, I resolutely concur with his hopeful call for collective resolve and increased global cooperation.

\section{Conclusion}

The first part of Economics in the Age of Covid-19 (Gans 2020a) outlines a scathing critique of the US political economy under Covid-19, providing more than adequate (if not exactly objective) rationale for the dismantling of the false health vs. wealth dichotomy in favor of a more rational health before wealth discourse. However, the second part of the book suffers from a lack of methodological rigor which allows a concise and eviscerating treatise of contemporary US-led Covid-19 'grim economic' discourse to devolve into an amateurish foray into a post-pandemic future built upon idealized neoliberal market-based notions of innovation and exclusionary forms of uneven global cooperation. Concerning this volume's methodological contribution to the development of an institutionalized ethics of inquiry within postdigital collective intelligence, highlighted by a Peircean understanding of 'truth reached by consensus within a community of inquirers' (Peters and Jandrić 2018: 154), this book may not be the best place to start. However, this statement comes with the understanding that Gans' work has yet to be concretized, as a final published version is expected to be released by November 2020 (Gans 2020b). Therefore, with Covid-19 continuing to provide a constant stream of challenges for the global community to collectively face (and hopefully overcome), perhaps the mercurial ontology of Gans' work may yet still allow novel insights to emerge.

\section{References}

Benkler, Y., Shaw, A., \& Hill, B. M. (2015). Peer production: A form of collective intelligence. In T. W. Malone \& M. S. Bernstein (Eds.), The handbook of collective intelligence (pp. 175-204). Cambridge: MIT Press.

Berger, M., Shammas, B., Berman, M., Wagner, J., Buckner, C., Brice-Saddler, M., ... Knowles, H. (2020). Coronavirus may still be spreading uncontrolled in 24 states, study suggests. The Washington Post, 23 
May. https://www.washingtonpost.com/nation/2020/05/22/coronavirus-update-us/. Accessed 24 May 2020.

Frias, L. (2020). The US is being presented with 2 choices: The economy or public health. Experts say it's a false dichotomy and there's a 3rd option. Business Insider, 6 May. https://www.businessinsider. com/experts-us-doesnt-have-to-choose-between-economy-public-health-2020-5. Accessed 23 May 2020.

Gans, J. (2020a). Economics in the Age of Covid-19. Cambridge, MA: MIT Press. https://doi.org/10.21428 /a11c83b7.c48fa91b.

Gans, J. (2020b). How I wrote and published a book about the economics of coronavirus in a month. The Conversation, 2 May. https://theconversation.com/how-i-wrote-and-published-a-book-about-theeconomics-of-coronavirus-in-a-month-137489. Accessed 23 May 2020.

Jandrić, P. (2017). Learning in the age of digital reason. Rotterdam: Sense.

Jandrić, P., Ryberg, T., Knox, J., Lacković, N., Hayes, S., Suoranta, J., Smith, M., Steketee, A., Peters, M., McLaren, P., Ford, D. R., Asher, G., McGregor, C., Stewart, G., Williamson, B., \& Gibbons, A. (2018). Postdigital Dialogue. Postdigital Science and Education, 1(1), 163-189. https://doi.org/10.1007/s42438018-0011-x.

Kelley, C. (2020). Chris Christie pushes to reopen country despite dire Covid-19 projections: 'There are going to be deaths'. CNN, 5 May. https://edition.cnn.com/2020/05/04/politics/chris-christie-coronavirus-deathsreopening/index.html. Accessed 23 May 2020.

Levin, B. (2020). Texas Lt. Governor: Old People Should Volunteer to Die to Save the Economy. Vanity Fair, 24 March. https://www.vanityfair.com/news/2020/03/dan-patrick-coronavirus-grandparents. Accessed 23 May 2020.

Malone, T. W., \& Bernstein, M. S. (2015). Introduction. In T. W. Malone \& M. S. Bernstein (Eds.), Handbook of collective intelligence (pp. 1-13). Cambridge, MA: MIT Press.

NBC News (2020). U.S. death toll tops 95,000. Coronavirus Live Blog, 23 May. https://www.nbcnews. com/health/health-news/live-blog/2020-05-22-coronavirus-news-n1212671. Accessed 23 May 2020.

Peters, M. A., \& Jandrić, P. (2018). The digital university: A dialogue and manifesto. New York: Peter Lang Publishing, Inc.

Saphir, A., \& Mason, J. (2020). The U.S. weighs the grim math of death vs. the economy. Reuters, 30 March. https://www.reuters.com/article/us-health-coronavirus-usa-reopen-analysi/the-u-s-weighs-the-grim-mathof-death-vs-the-economy-idUSKBN21H1B4. Accessed 23 May 2020.

The Economist (2020). A grim calculus. 4 April. https://www.economist.com/node/21783262/audio-edition. Accessed 23 May 2020.

Villa, L. (2020). How some anti-quarantine protests are being promoted by national Players With Ties to Trump. Time, 22 April. https://time.com/5825840/anti-quarantine-protests-organizers-trump/. Accessed 23 May 2020. 